\title{
MENINGKATKAN KEMAMPUAN MELAKUKAN OPERASI HITUNG PECAHAN PELAJARAN MATEMATIKA MELALUI PEMBELAJARAN KOOPERATIF TEKNIK PERMAINAN KARTU BAGI SISWA KELAS V MI MAARIF NU NURUL ULUM BULUREJO BENJENG
}

\author{
Nur Hudah \\ Pengawas Madrasah Kemenag Gresik \\ pengawasmiradamai@gmail.com
}

\begin{abstract}
Based on the author's experience in the field, many failures in the mathematics learning process faced by all students. Students feel bored, lazy and boring when faced with learning mathematics. To deal with such problems, the efforts made by the teacher are to arouse student learning motivation. Some things that can be done by the teacher so that learning mathematics becomes fun is to try various models and techniques in learning. One of the learning models used is cooperative learning of card game techniques. The problem examined in this study is how is the effort to increase the ability of students to perform fraction counting operations with cooperative learning of card game techniques? while the purpose of this study was to determine the ability to perform fraction counting operations after the application of cooperative learning in card game techniques. The researcher used Classroom Action Research which was conducted in two cycles or 2 rounds. Each cycle consists of planning, observation, reflection and discussion. The target of the research carried out is MI Ma'arif NU Class V Students Nurul Ulum Bulurejo Benjeng. The data obtained is the result of teacher observation, student activity data, and evaluation test results data. From the results of the analysis it was found that the increase in students' ability to perform fraction counting operations that can be seen from the evaluation test data. Obtaining results in cycle 1 with an average value of 63.6 or $60 \%$ completeness in cycle II the average value of students to be 91.44 or reach $92 \%$. The conclusion that can be drawn from this study is that cooperative learning methods can improve students' ability to perform fraction counting operations at MI Ma'arif NU Nurul Ulum Bulurejo Benjeng.
\end{abstract}

Keywords: Improve ability, fraction counting operations, cooperative learning

\begin{abstract}
ABSTRAK
Berdasarkan pengalaman penulis di lapangan, banyak kegagalan dalam proses pembelajaran matematika yand dihadapi oleh semua murid. Murid merasa jenuh, malas dan membosankan jika menghadapi pembelajaran Matematika. Untuk menghadapi permasalahan seperti itu ,upaya yang dilakukan oleh guru adalah membangkitkan motivasi belajar siswa. Beberapa hal yang bias dilakukan oleh Guru agar pembelajaran Matematika menjadi menyenangkan adalah dengan mencoba berbagai model dan teknik dalam pembelajaran. Salah satu model pembelajaran yang digunakan adalah pembelajaran kooperatif teknik permaianan kartu Permasalahan yang dikaji dalam penelitian ini adalah bagaimanakah upaya peningkatan klemampuan siswa dalam melakukan operasi hitung pecahan dengan pembelajaran kooperatif teknik permainan kartu? sedangkan tujuan dari penelitian ini adalah untuk mengetahui kemampuan melakukan operasi hitung pecahan setelah diterapkannya pembelajaran kooperatif teknik permaianan kartu. Peneliti menggunakan penelitian tindakan kelas ( Classroom action research) yang dilakukan sebanyak dua siklus atau 2 putaran. Setiap siklus terdiri dari perencanaan, pengamatan, refleksi dan pembahasan. Sasaran penelitian yang dilakukan adalahSiswa kelas V MI Ma'arif NU Nurul Ulum Bulurejo Benjeng. Data yang diperoleh adalah hasil dari observasi guru, data kegiatan siswa, dan data hasil tes evaluasi. Dari hasil analisis didapatkan bahwa peningkatan kemampuan siswa dalam melakukan operasi hitung pecahan yang dapat dilihat dari data hasil tes evaluasi. Perolehan hasil pada siklus 1 dengan nilai rata-rata 63,6 atau $60 \%$ nilai ketuntasan pada siklus II nilai rata-rata siswa menjadi 91,44 atau mencapai $92 \%$. Kesimpulan yang dapat diambil dari pebelitian ini adalah metode pembelajaran kooperatif dapat meningkatkan kemampuan siswa dalam melakukan operasiu hitung pecahan di MI Ma'arif NU Nurul Ulum Bulurejo Benjeng.
\end{abstract}

Kata Kunci: Meningkatkan kemampuan , operasi hitung pecahan, kooperatif learning

(C) (2020) Program Studi Pendidikan Guru Madrasah Ibtidaiyah

STAI Al-Azhar Menganti Gresik, Indonesia

Available online on: http://jurnal.stai-alazharmenganti.ac.id/index.php/BUNAYYA 


\section{Pendahuluan}

Pendidikan adalah investasi jangka panjang yang memerlukan usaha dan dana yang cukup besar, hal ini diakui oleh semua orang atau suatu bangsa demi kelangsungan masa depannya. Pendidikan merupakan investasi besar jangka panjang yang harus ditata, disiapkan dan diberikan sarana maupun prasarananya dalam arti modal material yang cukup besar, tetapi sampai saat ini Indonesia masih berkutat pada problematika (permasalahan) klasik dalam hal ini yaitu kualitas pendidikan.

Matematika adalah salah satu matapelajaran yang harus dikuasai oleh peserta didik yang juga merupakan salah satu cara mengembangkan pola berpikir oleh karena itu matematika sangat diperlukan baik untuk kehidupan sehari-hari maupun dalam menghadapi kemajuan IPTEK. Kenyataan yang terjadi justru banyaknya peserta didik yang kurang respon terhadap pelajaran ini. Anggapan peserta didik saat ini adalah bahwa matematika adalah pelajaran yang sulit dan menakutkan sehingga matematika dianggap sebagai momok. Demikian juga yang terjadi pada pembelajaran matematika di MI Ma'arif NU Nurul Ulum Bulurejo Benjeng . masih ada sebagian siswa yang kurang termotivasi dalam mengikuti pelajaran matematika dikelas. Hal ini juga dibuktikan dengan kurangnya respon dalam pelajaran matematika oleh sebagian siswa.

Pendidikan merupakan usaha sadar dan terencana untuk mewujudkan suasana belajar dan proses pembelajaran agar peserta didik secara aktif mengembangkan potensi dirinya ( Sisdiknas, 2003: 3). Guru wajib memiliki kualifikasi akademik, kompetensi serta memiliki kemampuan untuk mewujudkan tujuan pendidikan nasional (PP 74: 2008, 3). Sedangkan dalam melaksanakan tugasnya guru harus memiliki kompetensi. Makna dari Kompetensi guru adalah seperangkat pengetahuan, keterampilan, dan perilaku yang harus dimiliki, dihayati, dikuasai, dan diaktualisasikan oleh guru dalam melaksanakan tugas keprofesionalan (PP74: 2008)

Berangkat dari tugas dan kewajiban guru tersebut, Guru matematika harus membuka paradigma baru dalam pola pengajaran matematika di kelas. Kegiatan pembelajaran matematika dilakukan dengan mengaitkan antara pengembangan diri dengan proses pembelajaran dikelas melalui pengalaman-pengalaman belajar yang inovatif, menantang dan menyenangkan. Melihat kondisi lapangan dimana sebagian siswa masih ada yang lemah dalam melakukan operasi hitung pecahan matematika dan didukung dengan banyaknya anak- anak yang menggunakan waktu luangnya untuk bermain kartu gambar kartun maka perlu dilakukan beberapa upaya cara mengatasinya. Salah satu diantaranya adalah adanya upaya pembaharuan dalam proses pembelajaran dengan media yang menyenangkan. Upaya pembaharuan proses tersebut, terletak pada tanggung jawab guru, bagaimana pembelajaran yang disampaikan dapat dipahami oleh anak didik secara benar. Dengan demikian, proses pembelajaran ditentukan sampai sejauh guru dapat menggunakan metode dan model pembelajaran dengan baik. Model pembelajaran itu banyak macamnya, setiap model pembelajaran 
sangat ditentukan oleh tujuan pembelajaran dan kemampuan guru dalam mengelola proses pengajaran.

Salah satu model pembelajaran yang dapat mengakomodasi kepentingan untuk mengkolaborasikan pengembangan diri di dalam proses pembelajaran adalah model pembelajaran kooperatif (cooperative learning) dengan media permainan kartu. Ide penting dalam pembelajaran kooperatif adalah membelajarkan kepada siswa keterampilan kerjasama dan kolaborasi. Keterampilan ini sangat penting bagi siswa, karena pada dunia kerja sebagian besar dilakukan secara kelompok.

Pembelajaran kooperatif merupakan salah satu model pembelajaran yaitu siswa belajar dalam kelompok kecil yang heterogen dan dikelompokkan dengan tingkat kemampuan yang berbeda. Jadi dalam setiap kelompok terdapat peserta didik yang berkemampuan rendah, sedang, dan tinggi. Dalam menyelesaikan tugas, anggota saling bekerja sama dan membantu untuk memahami bahan pembelajaran. Belajar belum selesai jika salah satu teman belum menguasai bahan pembelajaran. Pemilihan model pembelajaran yang tepat dalam pembelajaran matematika akan mengaktifkan siswa serta menyadarkan siswa bahwa matematika tidak selalu membosankan. Guru hanya sebagai fasilitator untuk membentuk dan mengembangkan pengetahuan itu sendiri, bukan untuk memindahkan pengetahuan. Melalui pembelajaran kooperatif siswa diharapkan dapat meningkatkan kemampuan berpikir dan motivasi dalam belajar matematika.

Berdasarkan uraian diatas ,maka peneliti berkeinginan untuk mengadakan penelitian tindakan kelas dengan judul "Meningkatkan kemampuan melakukan operasi hitung pecahan pelajaran matematika melalui pembelajaran kooperatif learning teknik permainan kartu dikelas V MI Ma'arif NU Nurul Ulum Bulurejo Benjeng“

\section{Metode Penelitian}

Penelitian ini merupakan penelitian tindakan kelas (class action research) yang digunakan untuk mencari solusi atas permasalahan yang terjadi didalam proses pembelajaran di dalam kelas. Dalam penelitian ini, peneliti mempunyai peran yang besar terhadap proses dan hasil penelitian yang dilakukan dengan cara bekerjasama dengan guru bidang studi matematika dan juga rekan sejawat .

Dalam melakukan penelitian ini, peneliti terlibat langsung dalam melakukan proses pembelajaran sehingga peneliti lebih tahu kondisi yang sebenarnya terjadi pada siswa. Dengan keterlibatan yang langsung ini diharapkan hasil yang diperoleh dari penelitian ini lebih obyektif serta adanya ketercapaian tingkat validitas data yang diperoleh. Keberhasilan penelitian ini di hentikan jika ketuntasan menjadi 85\% atau lebih. Penelitian tindakan kelas (class action research) ini dilaksanakan selama 2 bulan yaitu bulan Januari sampai Maret 2020 Pada penelitian ini, materi pembelajaran yang dijadikan obyek adalah pelajaran matematika dengan standar kompetensi operasi hitung pecahan dengan kompetensi dasar melakukan operasi hitung pecahan. Tempat Penelitian tindakan kelas ini 
adalah siswa kelas V A di MI Ma'arif NU Nurul Ulum Bulurejo Benjeng tahun pelajaran 2019/2020 dengan jumlah siswa 25 orang yang terdiri dari 10 orang anak wanita dan 15 orang anak laki-laki

\section{Rancangan Penelitian}

Rancangan penelitian meliputi kegiatan sebelum pelaksanaan PTK dilanjutkan dengan pelaksanaan PTK selama dua siklus. Secara rinci kegiatan telah disampaikan sebagai berikut :

\begin{tabular}{|c|c|c|}
\hline \multirow{4}{*}{ SIKLUS I } & Perencanaan & $\begin{array}{l}\text { 1. Membuat rencana pembelajaran dengan menggunakan } \\
\text { metode kooperatif learning } \\
\text { 2. Membuat lembar observasi untuk mengetahui bagaiman } \\
\text { kondisi belajar mengajar dikelas baik ketika kelompok } \\
\text { maupun individu } \\
\text { 3. Mendesain alat evaluasi untuk melihat kemampuan siswa } \\
\text { pada setiap siklus }\end{array}$ \\
\hline & Tindakan & $\begin{array}{l}\text { 1. Melaksanakan tindakan sesuai dengan Rencana Pelaksanaan } \\
\text { Pembelajaran dan Lembar kerja Siswa }\end{array}$ \\
\hline & Pengamatan & $\begin{array}{l}\text { 1. Melakukan observasi sesuai format yang telah disipakan } \\
\text { 2. Menilai hasil tindakan sesuai dengan format yang telah } \\
\text { disiapkan }\end{array}$ \\
\hline & Refleksi & $\begin{array}{l}\text { 1. Melakukan evaluasi proses KBM dan ketersediaan waktu } \\
\text { 2. Memperbaiki pelaksanaan tindakan sesuai dengan evaluasi } \\
\text { untuk dilaksanakan pada siklus berikutnya }\end{array}$ \\
\hline \multirow{4}{*}{ SIKLUS II } & perencanaan & $\begin{array}{l}\text { 1. Penentuan alternative problem solving } \\
\text { 2. Pengembangan program tindakan selanjutnya }\end{array}$ \\
\hline & Tindakan & $\begin{array}{l}\text { 1. Melaksanakan tindakan kedua sesuai dengan Rencana } \\
\text { Pembelajaran dan Lembar Kerja siswqa berdasrkan perbaikan } \\
\text { siklus I }\end{array}$ \\
\hline & Pengamatan & 1. Pengumpulan dan analisis tindakan kedua \\
\hline & Refleksi & $\begin{array}{l}\text { 1. Evaluasi komperehensif, untuk dijadikan dasar penentuan } \\
\text { nilai }\end{array}$ \\
\hline
\end{tabular}

\section{Instrumen penelitian}

Instrument yang digunakan dalam penelitian ini adalah :

a. Silabus

b. Rencana Pelaksanaan Pembelajaran (RPP)

c. Lembar observasi aktifitas guru dan siswa

Lembar observasi kegiatan guru dan siswa dipergunakan untuk melakukan pengamatan terhadap aktivitas guru dan siswa selama PTK .

d. Lembar Observasi Kegiatan Kelompok siswa

Lembar observasi kegiatan kelompok siswa digunakan untuk mengamati aktifitas siswa selama melaksanakan proses pembelajaran baik saat kegiatan kelompok, maupun individu. Hasil pengamatan tersebut dijadikan acuan untuk refleksi.

e. Lembar kerja kelompok

Lembar kerja kelompok adalah lembar kerja yang dikerjakan oleh siswa dan diselesaikan dengan cara kerja kelompok

\section{f. Tes formatif}

Test formatif di desain berdasarkan tujuan pembelajaran yang akan dicapai 


\section{Metode Pengumpulan Data}

Data-data yang diperlukan dalam penelitian ini diperoleh melalui observasi pengolahan pembelajaran melakukan operasi hitung pecahan pada pelajaran Matematika, observasi kelas, observasi aktivitas siswa dan guru, serta hasil tes evaluasi.

\section{Teknik analisis data}

Analisis penelitian dilakukan secara deskriptif kualitatif dan kuantitatif berdasarkan hasil observasi terhadap proses dan hasil belajar siswa ,angket, wawancara, dan studi dokumentasi hasil kerja siswa dengan langkah sebagai berikut:

a. Melakukan reduksi, yaitu mengecek dan mencatat kembali data-data yang telah terkumpul

b. Melakukan interpretasi, yaitu menafsirkan selanjutnya diwujudkan dalam bentuk pernyataan

c. Melakukan analisis hasil observasi guru terhadap pelaksanaan diskusi

d. Melakukan analisis terhadap hasil pengamatan guru terhadap presentasi siswa

e. Melakukan analisis dari hasil wawancara dengan siswa dan observer

f. Melakukan analisis Kuantitatif, yaitu menyimpulkan apakah dalam tindakan pembelajaran ini terjadi peningkatan proses dan hasil belajar siswa atau tidak berdasarkan hasil observasi yang dilaksanakan bersama observer.

g. Tahap tindak lanjut, yaitu merumuskan langkah-langkah perbaikan siklus selanjutnya

h. Pengambilan kesimpulan, diambil berdasarkan analisis hasil observasi yang disesuaikan dengan tujuan penelitian, kemudian di tuangkan dalam bentuk interpreatsi berupa kalimat pernyataan

Analisis data hasil evaluasi siswa dalam bentuk tes tertulis dilakukan dengan menggunakan analisis statistik sederhana :

a. Penilaian tes ulangan tiap siklus

Untuk menghitung rata -rata kelas pada masing-masing siklus digunakan rumus :

$$
X=\Sigma \mathrm{x}
$$

$\mathrm{n}$

$$
\begin{array}{ll}
\mathrm{X} & =\text { rata }- \text { rata kelas } \\
\Sigma \mathrm{x} & =\text { jumlah seluruh skor } \\
\mathrm{n} & =\text { banyaknya siswa }
\end{array}
$$

b. Untuk menghitung

Ada dua katagori criteria ketuntasan minimal secara individu dan secara kelompok. seorang siswa dikatakan berhasil (mencapai ketuntasan) belajar bila telah mencapai taraf pengauasaan $75 \%$ atau dengan nilai 70 . Untuk mengetahuiketuntasan belajar klasikal digunakan Rumus :

$$
\mathrm{P}=\frac{\mathrm{B}}{\mathrm{N}} \times 100 \%
$$

Keterangan:

$\mathrm{P} \quad=$ Pencapaian presentasi

B = banyak siswa yang mendapat nilai dibawah KKM

$\mathrm{N} \quad=$ jumlah siswa yang mengikuti tes 


\section{Hasil Penelitian}

Pada bagian ini peneliti memaparkan mengenai kondisi lapangan pada saat tindakan pembelajaran berlangsung, yaitu merekam semua aspek yang terjadi pada waktu penelitian .

Supaya situasi pembelajaran dapat diikuti secara utuh, maka peneliti memaparkan semua proses yang terjadi selama berlangsungnya pembelajaran mulai dari awal sampai peneliti menutup pembelajaran. Dalam pengumpulan data penelitian yang diperoleh berupa hasil tes formatif, pengamatan dan aktifitas guru pada setiap siklus.

Data pada setiap siklus akan dianalisis dan diolah untuk mengukur tingkat perubahan hasil belajar siswa secara kualitatif .Hasil pembelajaran akan dijadikan pijakan untuk menentukan dan merencanakan langkah pada siklus selanjutnya.

\section{Perencanaan data Penelitian pada siklus I}

\section{a. Perencanaan}

Pada tahap ini peneliti menyiapkan perangkat pembelajaran dengan membuat rencana pembelajaran (RPP), Lembar Kerja, bahan ajar, lembar observasi, kartu media, lembar penilaian. Rencana pelaksanaan pembelajaran, Lembar kerja siswa, kartu media didesain sesuai dengan materi yang dijadikan obyek penelitian. Membuat lembar observasi untuk mengetahui bagaimana kondisi belajar mengajar dikelas baik ketika kelompok maupun individu

\section{b. Pelaksanaan}

Untuk melaksanakan Tindakan penelitian kelas (PTK) agar sesuai dengan RPP dan lembar observasi yang telah dibuat untuk mengetahui bagaimana kondisi belajar mengajar dikelas baik ketika kelompok maupun individu, dalam hal ini peneliti juga bertindak sebagai guru yang mengajarkan materi tersebut. Pada proses belajar mengajar digunakan pendekatan pembelajaran kooperatif dengan menggunakan media kartu pecahan.

Adapun tahapan yang dilakukan adalah presensi kelas, kerja kelompok, tes individu, skor pengembangan individu dan penghargaan kelompok. Hasil test formatif akan dijadikan acuan untuk menentukan nilai dan ketercapaian KKM individual atau klasikal, sehingga peneliti mendapatkan data hasil evaluasi yang valid untuk menetapkan jumlah siswa yang tuntas atau belum tuntas pada siklus I pada pelaksanaannya siklus satu dilaksanakan pada tanggal 15 Januari 2020 di kelas VA dengan jumlah siswa 25 Orang. 


\section{DAFTAR NILAI PTK MI NU UNGGULAN WARU SIDOARJO MATA PELAJARAN MATEMATIKA KELAS V SIKLUS II}

Tabel 1.1 Hasil Tes evaluasi siklus 1

\begin{tabular}{|c|c|c|c|c|c|}
\hline No & Nama & KKM & Nilai & Tuntas & $\begin{array}{l}\text { Belum } \\
\text { Tuntas }\end{array}$ \\
\hline 1. & Ahmad Sanjay Nurdin & 70 & 50 & & $\sqrt{ }$ \\
\hline 2. & Adjie Yunanai Kurniawan & 70 & 60 & & $\sqrt{ }$ \\
\hline 3. & Agam Rasirin Qouhmal & 70 & 60 & & $\sqrt{ }$ \\
\hline 4. & Aimee Izzul Imni & 70 & 20 & & $\sqrt{ }$ \\
\hline 5. & Cindy Arinati Wibowo & 70 & 100 & $\sqrt{ }$ & \\
\hline 6. & Devi Agus Lestari & 70 & 20 & & $\sqrt{ }$ \\
\hline 7. & Elmin Luqita Sari & 70 & 0 & & $\sqrt{ }$ \\
\hline 8. & Erina Evida Aulia & 70 & 100 & $\sqrt{ }$ & \\
\hline 9. & Fakruzy Hakim Rasia & 70 & 100 & $\sqrt{ }$ & \\
\hline 10. & Ikillah Muzayyanah & 70 & 100 & $\sqrt{ }$ & \\
\hline 11. & Imamul baihaqi & 70 & 85 & $\sqrt{ }$ & \\
\hline 12. & Ismail & 70 & 80 & $\sqrt{ }$ & \\
\hline 13. & M. Abid Abdillah & 70 & 70 & $\sqrt{ }$ & \\
\hline 14. & M. Habibullah & 70 & 0 & & $\sqrt{ }$ \\
\hline 15. & M. Hendriansyah & 70 & 80 & $\sqrt{ }$ & \\
\hline 16. & M. Iqbal Alvishar & 70 & 100 & $\sqrt{ }$ & \\
\hline 17. & M. Kemal Jamaludin & 70 & 100 & $\sqrt{ }$ & \\
\hline 18. & Muhammad Thoriq Rizqullah & 70 & 100 & $\sqrt{ }$ & \\
\hline 19. & Maulana Al Farisi & 70 & 100 & $\sqrt{ }$ & \\
\hline 20. & Mohammad Aji Nugraha & 70 & 85 & $\sqrt{ }$ & \\
\hline 21. & Nabillah Rohadatul Aisiyah & 70 & 80 & $\sqrt{ }$ & \\
\hline 22. & Putri Wulandari Sri Agustin & 70 & 0 & & $\sqrt{ }$ \\
\hline 23. & Violita Vernanda & 70 & 0 & & $\sqrt{ }$ \\
\hline 24. & Zidni Ilman Nafi' & 70 & 0 & & $\sqrt{ }$ \\
\hline \multirow[t]{4}{*}{25} & Aulia rahma & 70 & 100 & $\sqrt{ }$ & \\
\hline & Jumlah & & 1590 & 15 & 10 \\
\hline & Nilai Rata-rata & & 63,6 & & \\
\hline & Persentase Ketuntasan Kolektif & & & $60 \%$ & $40 \%$ \\
\hline
\end{tabular}

Berdasarkan data hasil evaluasi di atas, dapat diketahui bahwa ketuntasan anak masih belum maksimal karena masih ada anak yang belum memenuhi ketuntasan minimal atau nilai 70 ( sesuai KKM ). Dari 25 anak yang masih dibawah nilai ketuntasan minimal masih ada 10 orang anak. Hal ini disebabkan karena kemampuan anak yang homogen.Untuk mengetahui perkembangan anak yang terjadi selama penelitian tindakan kelas peneliti menggunakan lembar observasi, hasil observasi pada siklus I dapat dilihat pada table sebagai berikut :

Tabel 2.1 Instrumen Observasi kegiatan siswa Siklus I

\begin{tabular}{|c|c|c|c|c|c|}
\hline No & Aspek yang diamati & $\mathrm{BS}$ & $\mathrm{B}$ & $\mathrm{C}$ & $\mathrm{K}$ \\
\hline 1. & Antusiasme siswa mengikuti KBM & & $\sqrt{ }$ & & \\
\hline 2. & $\begin{array}{l}\text { Kelancaran siswa mengemukakan } \\
\text { memecahkan masalah }\end{array}$ & & & $\sqrt{ }$ & \\
\hline 3. & Keaktifan siswa dalam diskusi & & $\sqrt{ }$ & & \\
\hline 4. & Kemampuan siswa dalam menghimpun hasil diskusi & & $\sqrt{ }$ & & \\
\hline 5. & Keaktifan dalam Bertanya Pada proses diskus kelompok & & & $\sqrt{ }$ & \\
\hline 6. & Keaktifan siswa dalam Mencari Sumber Belajar & & $\sqrt{ }$ & & \\
\hline 7. & Kelancaran siswa dalam menjawab pertanyaan & & $\sqrt{ }$ & & \\
\hline
\end{tabular}


BS

B : Baik

C : Cukup

K : Kurang

MUHARIR

$\mathrm{Nb}$ : Beri tanda $\sqrt{\text { bila sesuai keterangan }}$

Berdasarkan tabel 2 diatas, dapat diketahui antusiasme siswa mengikuti pembelajaran baik sekali. Bahwa telah terjadi interaksi siswa selama PBM (interaksi antar siswa, siswa dengan guru, kemampuan siswa mengemukakan gagasannya pada diskusi kelompok cukup baik, keberanian siswa bertanya dan mengeluarkan pendapat dalam PBM dengan hasil cukup. partisipasi siswa dalam mengerjakan tugas kelompok. Kemampuan siswa mengemukakan, dan respon siswa terhadap berbagai pertanyaan dari kelompok lain cukup baik. Hubungan antar siswa ditinjau dari keakraban, kerjasama, dan kompetisi dengan hasil baik.

Tabel 3.1 Instrumen Observasi kegiatan kelompok siswa Siklus I.

\begin{tabular}{|c|c|c|c|c|c|c|}
\hline \multirow[t]{2}{*}{ No } & \multirow{2}{*}{$\begin{array}{c}\text { Aspek Yang } \\
\text { Diobservasikan }\end{array}$} & \multicolumn{5}{|c|}{ Kelompok } \\
\hline & & 1 & 2 & 3 & 4 & 5 \\
\hline 1. & Aktif berdiskusi & $\sqrt{ }$ & $\sqrt{ }$ & $\sqrt{ }$ & $\sqrt{ }$ & $\sqrt{ }$ \\
\hline 2. & Aktif mencari sumber belajar & $\sqrt{ }$ & & $\sqrt{ }$ & $\sqrt{ }$ & $\sqrt{ }$ \\
\hline 3. & Efektivitas pemanfaatan waktu & $\sqrt{ }$ & $\sqrt{ }$ & $\sqrt{ }$ & $\sqrt{ }$ & $\sqrt{ }$ \\
\hline 4. & Partisipasi setiap anggota kelompok & & $\sqrt{ }$ & $\sqrt{ }$ & $\sqrt{ }$ & $\sqrt{ }$ \\
\hline 5. & Kelancaran pada saat persentasi & $\sqrt{ }$ & $\sqrt{ }$ & $\sqrt{ }$ & $\sqrt{ }$ & $\sqrt{ }$ \\
\hline 6. & Kelancaran menjawab pertanyaan antar kelompok & $\sqrt{ }$ & $\sqrt{ }$ & $\sqrt{ }$ & & $\sqrt{ }$ \\
\hline 7. & Memahami tugas masing-masing kelompok & $\sqrt{ }$ & $\sqrt{ }$ & $\sqrt{ }$ & $\sqrt{ }$ & $\sqrt{ }$ \\
\hline 8. & Kemampuan menyimpulkan hasil diskusi & $\sqrt{ }$ & $\sqrt{ }$ & $\sqrt{ }$ & $\sqrt{ }$ & $\sqrt{ }$ \\
\hline 9. & Kemampuan mengemukakan ide & $\sqrt{ }$ & $\sqrt{ }$ & $\sqrt{ }$ & $\sqrt{ }$ & $\sqrt{ }$ \\
\hline 10. & Kekompakan kelompok & & $\sqrt{ }$ & $\sqrt{ }$ & $\sqrt{ }$ & $\sqrt{ }$ \\
\hline
\end{tabular}

Beri tanda $\sqrt{ }$ bila sesuai

Keterangan: $\quad$ Perlu penambahan waktu untuk kegiatan diskusi dan siswa masih belum memahami tugas masing-masing kelompok

Kolaborator

Muharir

Berdasarkan tabel diatas keaktifan kelompok dalam kegiatan diskusi cukup baik. keaktifan kelompok dalam mencari sumber belajar, akan tetapi pada proses merata. pada siklus I masing-masing kelompok kurang memahami tugasnya. pada hubungan antar siswa ditinjau dari keakraban, kerjasama, kemampuan mengemukakan ide dan menyimpulkan hasil diskusi masih membutuhkan bimbingan lebih lanjut dari guru. kekompakan siswa dalam kerja kelompok pemecahan masalah masih belum merata

Tabel 4.1 Instrumen Observasi Kegiatan guru Siklus I.

\begin{tabular}{rlccc}
\hline No & \multicolumn{1}{c}{ Kegiatan } & Ya & Tidak \\
\hline A. & Pendahuluan & & \\
\hline 1. & Guru Melakukan Apersepsi & $\sqrt{ }$ & \\
\hline 2. & Guru Memberikan Motivasi & $\sqrt{ }$ & \\
\hline 3. & Guru Memberikan Tujuan Yang akan dicapai & $\sqrt{ }$ & \\
\hline 4. & Guru menjelaskan langkah-langkah KBM & & $\sqrt{ }$ \\
\hline B. & Kegiatan Inti & & \\
\hline
\end{tabular}




\begin{tabular}{clc}
\hline 1. & Guru Mengelompokkan siswa & $\sqrt{ }$ \\
\hline 2. & Guru Mengontrol Kesiapan Diskusi & $\sqrt{ }$ \\
\hline 3. & Guru Mengamati peoses Diskusi & $\sqrt{ }$ \\
\hline 4. & Guru mengintervensi terhadap jalannya diskusi & $\sqrt{ }$ \\
\hline 5. & Guru melaksanakan diskusi kelas & $\sqrt{ }$ \\
\hline 6. & Guru memberikan Penguatan dan Reinforcerman & $\sqrt{ }$ \\
\hline C. & Penutup & $\sqrt{ }$ \\
\hline 1. & Melaksanakan Evaluasi & \\
\hline 2. & Membuat kesimpulan dari Hasil Diskusi siswa
\end{tabular}

Beri tanda $\sqrt{ }$ bila sesuai

Keterangan: Perlu ada bimbingan dan arahan dari guru untuk melancarkan proses Diskusi.

Berdasarkan tabel diatas keaktifan guru selama proses KBM adalah melaksanakan pembelajaran Kooperatif teknik permaianan kartu yang disesuaikan dengan RPP. Aktivitas guru dalam pembelajaran, melakukan apersepsi, memberikan motivasi, menjelaskan langkahlangkah KBM, hal ini dilakukan untuk membangkitkan semangat memberikan gambaran kepada siswa tentang kegiatan pembelajaran. Pada proses kegiatan ini guru melakukan pembimbingan dan kontrol terhadap pelaksanaan diskusi untuk memastikan bahwa kegiatan diskusi berjalan sesuai dengan yang diharapkan, namun pada tahap ini masih ada beberapa hal yang terlupakan sehingga akan diperbaiki pada siklus selanjutnya.

\section{Analisis data penelitian pada siklus II}

\section{a. Perencanaan}

Pada tahap ini peneliti mempersiapkan perangkat pembelajaran, seperti RPP 2, LKS

2, Bahan Ajar 2, lembar observasi 2 untuk melihat bagaimana kondisi belajar mengajar dikelas ketika latihan dan kerja kelompok dilaksanakan, mendesain alat evaluasi berdasarkan perkembangan pada siklus I serta menyiapkan instrumen pendukung pembelajaran lainnya.

\section{b. Pelaksanaan}

Pelaksanaan Tindakan disesuaikan dengan Rencana Pelaksanaan Pembelajaran dan lembar Observasi yang telah dibuat dan mengacu pada revisi pada siklus I, sehingga kekeliruan pada siklus I tidak terulangi lagi pada siklus II. dalam hal ini peneliti bertindak sebagai guru. pada proses belajar mengajar digunakan pendekatan pembelajaran kooperatif teknik permainan Kartu dengan tahapan, Persentasi Kelas, Kerja kelompok, tes Individu, skor pengembangan individu dan penghargaan kelompok. hasil tes formatif akan dijadikan acuan untuk menentukan nilai dan ketercapaian KKM individual atau klasikal, sehingga peneliti akan mendapatkan data hasil evaluasi yang valid untuk menetapkan jumlah siswa yang tuntas atau belum pada siklus II. Pada akhir proses belajar mengajar siswa diberikan tes evaluasi pada siklus II dengan tujuan untuk mengetahui perubahan hasil belajar mengajar yang sudah dilaksanakan, kemudian dikomparasikan dengan hasil pada siklus I. Pengamatan (Observasi) dilaksanakan bersamaan dengan pelaksanakaan belajar mengajar yang dilakukan oleh teman sejawat adapun data hasil tes evaluasi pada Siklus II. 


\section{DAFTAR NILAI PTK MI MAARIF NU NURUL ULUM BULUREJO BENJENG MATA PELAJARAN MATEMATIKA KELAS V SIKLUS II}

Tabel 2.1 Hasil Tes pada siklus II

\begin{tabular}{|c|c|c|c|c|c|}
\hline No & Nama & KKM & Nilai & Tuntas & $\begin{array}{l}\text { Belum } \\
\text { Tuntas }\end{array}$ \\
\hline 1 & Ahmad Sanjay Nurdin & 70 & 88 & $\sqrt{ }$ & \\
\hline 2 & Adjie Yunanai Kurniawan & 70 & 100 & $\sqrt{ }$ & \\
\hline 3 & Agam Rasirin Qouhmal & 70 & 100 & $\sqrt{ }$ & \\
\hline 4 & Aimee Izzul Imni & 70 & 100 & $\sqrt{ }$ & \\
\hline 5 & Cindy Arinati Wibowo & 70 & 88 & $\sqrt{ }$ & \\
\hline 6 & Devi Agus Lestari & 70 & 100 & $\sqrt{ }$ & \\
\hline 7 & Elmin Luqita Sari & 70 & 75 & $\sqrt{ }$ & \\
\hline 8 & Erina Evida Aulia & 70 & 100 & $\sqrt{ }$ & \\
\hline 9 & Fakruzy Hakim Rasia & 70 & 100 & $\sqrt{ }$ & \\
\hline 10 & Ikillah Muzayyanah & 70 & 100 & $\sqrt{ }$ & \\
\hline 11 & Imamul baihaqi & 70 & 100 & $\sqrt{ }$ & \\
\hline 12 & Ismail & 70 & 88 & $\sqrt{ }$ & \\
\hline 13 & M. Abid Abdillah & 70 & 100 & $\sqrt{ }$ & \\
\hline 14 & M. Habibullah & 70 & 50 & & $\sqrt{ }$ \\
\hline 15 & M. Hendriansyah & 70 & 80 & $\sqrt{ }$ & \\
\hline 16 & M. Iqbal Alvishar & 70 & 100 & $\sqrt{ }$ & \\
\hline 17 & M. kemal Jamaludin & 70 & 100 & $\sqrt{ }$ & \\
\hline 18 & Muhammad Thoriq Rizqullah & 70 & 87 & $\sqrt{ }$ & \\
\hline 19 & Maolana Al Farisi & 70 & 100 & $\sqrt{ }$ & \\
\hline 20 & Mohammad Aji Nugraha & 70 & 100 & $\sqrt{ }$ & \\
\hline 21 & Nabillah Rohadatul Aisiyah & 70 & 80 & $\sqrt{ }$ & \\
\hline 22 & Putri Wulandari Sri Agustin & 70 & 63 & 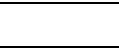 & $\sqrt{ }$ \\
\hline 23 & Violita Vernanda & 70 & 100 & $\sqrt{ }$ & \\
\hline 24 & Zidni Ilman Nafi' & 70 & 87 & $\sqrt{ }$ & \\
\hline \multirow[t]{4}{*}{25} & Aulia rahma & 70 & 100 & $\sqrt{ }$ & \\
\hline & Jumlah & & 2286 & 23 & 2 \\
\hline & Nilai Rata-rata & & 91,44 & & \\
\hline & Persentase Ketuntasan Kolektif & & & $92 \%$ & $8 \%$ \\
\hline
\end{tabular}

Berdasarkan data hasil evaluasi diatas diperoleh nilai rata-rata 91,44 pada siklus II, hasil ini menunjukkan adanya peningkatan hasil dibandingkan nilai rata-rata pada siklus I sebesar 63,6 dari hasil 25 siswa/siswi yang telah tuntas pada siklus II sebanyak 23 siswa atau 92\% dan 2 siswa yang belum tuntas. secara klasikal ketuntasan belajar pada siklus II telah mencapai sebesar 92\%. hasil belajar pada siklus II mengalami peningkatan secara kualitatif dan kuantitatif dibandingkan hasil pada siklus I. Peningkatan hasil pada siklus II disebabkan karena siswa sudah memahami metode yang akan digunakan sehingga siswa lebih mempersiapkan diri untuk belajar dan lebih mudah memahami materi pelajaran.Adanya peningkatan kemampuan guru dibandingkan pada siklus I, sehingga kekeliruan yang terjadi pada siklus I tidak terulang lagi pada siklus II hasil belajar pada siklus I dan II ketuntasan klasikal telah tercapai sehingga penelitian ini hanya sampai pada siklus II. 
Rekaman proses belajar mengajar selama PTK berlangsung pada siklus II dapat dilihat pada tabel berikut :

Tabel 2.2 Instrumen Observasi kegiatan siswa Siklus II.

\begin{tabular}{|c|c|c|c|c|}
\hline No & Aspek yang diamati & BS & B & $\mathrm{K}$ \\
\hline 1. & Antusiasme siswa mengikuti KBM & $\sqrt{ }$ & & \\
\hline 2 & $\begin{array}{l}\text { Kelancaran siswa mengemukakan ide-ide untuk memecahkan } \\
\text { masalah }\end{array}$ & & & $\sqrt{ }$ \\
\hline 3 & Keaktifan siswa dalam diskusi & & $\sqrt{ }$ & \\
\hline 4 & Kemampuan siswa dalam menghimpun hasil diskusi & & $\sqrt{ }$ & \\
\hline 5 & Keaktifan dalam Bertanya Pada proses diskus kelompok & & & $\sqrt{ }$ \\
\hline 6 & Keaktifan siswa dalam Mencari Sumber Belajar & & $\sqrt{ }$ & \\
\hline 7 & Kelancaran siswa dalam menjawab pertanyaan & & $\sqrt{ }$ & \\
\hline & Baik Sekali & & & \multirow{4}{*}{ Pengamat } \\
\hline & Baik & & & \\
\hline & : Cukup & & & \\
\hline & : Kurang & & & \\
\hline Beri & anda $\sqrt{ }$ bila sesuai keterangan & & & Nur Huda \\
\hline
\end{tabular}

Berdasarkan tabel 2.2 diatas, dapat diketahui antusiasme siswa/siswi mengikuti pembelajaran dengan sangat baik. bahwa telah terjadi interaksi selama PBM (interaksi antar siswa, siswa dengan guru, kemampuan siswa mengemukakan gagasannya pada diskusi kelompok yang baik, keberanian siswa bertanya dan mengeluarkan pendapat dalam mengerjakan tugas kelompok juga baik. kemampuan siswa mengemukakan, dan respon siswa terhadap berbagai pertanyaan dari kelompok lain baik. hubungan antar siswa ditinjau dari keakraban, kerjasama, dan kompetisi dengan baik. dari penjelasan ini bahwa ada peningkatan kualitas pembelajaran dibandingkan dengan siklus I.

Tabel 3.2 Instrumen Observasi kegiatan kelompok siswa siklus II.

\begin{tabular}{|l|l|l|l|l|l|c|}
\hline No & \multicolumn{1}{|c|}{$\begin{array}{c}\text { Aspek Yang } \\
\text { Diobservasikan }\end{array}$} & 1 & 2 & 3 & 4 & 5 \\
\hline 1 & Aktif berdiskusi & $\sqrt{ }$ & $\sqrt{ }$ & $\sqrt{ }$ & $\sqrt{ }$ & $\sqrt{ }$ \\
\hline 2 & Aktif mencari sumber belajar & $\sqrt{ }$ & $\sqrt{ }$ & $\sqrt{ }$ & $\sqrt{ }$ & $\sqrt{ }$ \\
\hline 3 & Efektivitas pemanfaatan waktu & $\sqrt{ }$ & $\sqrt{ }$ & $\sqrt{ }$ & $\sqrt{ }$ & $\sqrt{ }$ \\
\hline 4 & Partisipasi setiap anggota kelompok & $\sqrt{ }$ & $\sqrt{ }$ & $\sqrt{ }$ & $\sqrt{ }$ & $\sqrt{ }$ \\
\hline 5 & Kelancaran pada saat persentasi & $\sqrt{ }$ & $\sqrt{ }$ & $\sqrt{ }$ & $\sqrt{ }$ & $\sqrt{ }$ \\
\hline 6 & Kelancaran menjawab pertanyaan antar kelompok & $\sqrt{ }$ & $\sqrt{ }$ & $\sqrt{ }$ & $\sqrt{ }$ & $\sqrt{ }$ \\
\hline 7 & Memahami tugas masing-masing kelompok & $\sqrt{ }$ & $\sqrt{ }$ & $\sqrt{ }$ & $\sqrt{ }$ & $\sqrt{ }$ \\
\hline 8 & Kemampuan menyimpulkan hasil diskusi & $\sqrt{ }$ & $\sqrt{ }$ & $\sqrt{ }$ & $\sqrt{ }$ & $\sqrt{ }$ \\
\hline 9 & Kemampuan mengemukakan ide & $\sqrt{ }$ & & $\sqrt{ }$ & $\sqrt{ }$ & $\sqrt{ }$ \\
\hline 10 & Kekompakan kelompok & $\sqrt{ }$ & $\sqrt{ }$ & $\sqrt{ }$ & $\sqrt{ }$ & $\sqrt{ }$ \\
\hline
\end{tabular}

Beri tanda $\sqrt{ }$ bila sesuai

Keterangan: Perlu bimbingan khusus kelompok 2 untuk meningkatkan kemampuan menyimpulkan hasil Diskusi kelompok.

Kolaborator

Muharir

Berdasarkan tabel diatas terjadi peningkatan yang sangat baik terhadap perkembangan aktivitas kelompok . Kelompok 1-4 telah mampu melakukan diskusi dengan 
baik, hal ini berpengaruh pada peningkatan hasil belajar siswa. Peningkatan hasil belajar siswa/siswi dapat dilihat pada tebel 2 siklus II.

Tabel 3.2 Instrumen Observasi kegiatan guru Siklus II

\begin{tabular}{|c|c|c|c|}
\hline No & Kegiatan & Ya & Tidak \\
\hline \multicolumn{4}{|c|}{ A. Pendahuluan } \\
\hline 1. & Guru Melakukan Apersepsi & $\sqrt{ }$ & \\
\hline 2. & Guru Memberikan Motivasi & $\sqrt{ }$ & \\
\hline 3. & Guru Memberikan Tujuan Yang akan dicapai & $\sqrt{ }$ & \\
\hline & Guru menjelaskan langkah-langkah KBM & $\sqrt{ }$ & \\
\hline \multicolumn{4}{|c|}{ B. Kegiatan Inti } \\
\hline & Guru Mengelompokkan siswa & $\sqrt{ }$ & \\
\hline & Guru Mengontrol Kesiapan Diskusi & $\sqrt{ }$ & \\
\hline & Guru Mengamati peroses Diskusi & $\sqrt{ }$ & \\
\hline & Guru mengintervensi terhadap jalannya diskusi & $\sqrt{ }$ & \\
\hline 5. & Guru melaksanakan diskusi kelas & $\sqrt{ }$ & \\
\hline & Guru memberikan Penguatan dan Reinforcerman & $\sqrt{ }$ & \\
\hline \multicolumn{4}{|c|}{ C. Penutup } \\
\hline & Melaksanakan Evaluasi & $\sqrt{ }$ & \\
\hline & Membuat kesimpulan dari Hasil Diskusi siswa & $\sqrt{ }$ & \\
\hline
\end{tabular}

Beri tanda $\sqrt{ }$ bila sesuai

\section{Keterangan:}

Berdasarkan analisis data, yang diperoleh dari hasil aktivitas guru dengan model pembelajaran kooperatif teknik permainan kartu yang paling dominan dalam pembelajaran adalah siswa, siswa terlibat secara utuh lewat diskusi kelompok, permainan kartu, persentase hasil, guru hanyalah sebagai partner yang bertugas memberkan motivasi, menjelaskan tujuan pembelajaran serta langkah-langkah KBM sehingga siswa memahami orientasi pembelajaran. Pelaksanaan pembelajaran dapat dikatakan sudah sesuai dengan RPP yang sudah disiapkan.

\section{c. Refleksi}

Pada tahap ini akan merefleksikan kembalai apa yang telah dilaksanakan selama peneliti tindakan kelas dilakukan dari data yang diperoleh dapat diuraikan :

1) Selama proses belajar mengajar guru telah melaksanakan pembelajaran dengan cukup baik denga model pembelajaran kooperatif teknik permainan Kartu, meskipun ada beberapa bagian yang masih belum sempurna, tetapi prosentasi pelaksanaan untuk masing-masing kegiatan cukup baik.

2) Berdasarkan data hasil lembar onservasi siswa, tingkat keaktifan, kemampuan meyampikan ide dan merangkum hasil diskusi kelompok siswa semakin meningkat dari siklus I ke Siklus II.

3) Kekurangan pada siklus I di perbaiki sehingga tidak terjadi pada siklus II.

4) Hasil belajar siswa mengalami peningkatan secara kualitatif dan kuantitatif dari siklus I ke Siklus II. 


\section{Simpulan}

Setelah melakukan pengamatan dengan seksama dari hasil penelitian tindakan kelas ( PTK ) yang dilaksanakan oleh peneliti di Madrasah Ibtidaiyah Nahdlatul Ulama Waru 1 Sidoarjo selama dua bulan. dari hasil pembelajaran yang sudah dilakukan sebanyak 2 siklus dan pembahasan seluruh proses serta analisis yang sudah dilakukan maka peneliti dapat menyimpulkan hasil penelitian sebagai berikut (1)Pelaksanaan pembelajaran kooperatif learning teknik permainan kartu dapat meningkatkan kemampuan siswa dalam melakukan operasi hitung pecahan pelajaran Matematika. Hal ini ditandai dengan peningkatan hasil belajar secara kualitatif dan kuantitatif pada setiap siklus yaitu pada siklus (2)nilai rata-rata yang diperoleh sebesar 63,6 sedangkan ketuntasan belajar secara klasikal yaitu 60\% atau 15 siswa dari 25 siswa. Pada siklus II terjadi peningkatan hasil belajar dengan nilai rata-rata 91,44 dari 25 siswa. Secara klasikal ketuntasan belajar pada siklus II telah mencapai sebesar 92\%. yaitu sebanyak 23 siswa dari 25 siswa yang tuntas belajarnya.

Penerapan Pembelajaran Kooperatif Learning teknik permainan kartu dapat meningkatkan motivasi siswa yang ditujukkan dengan jawaban dan antusiasme siswa dalam mengikuti proses belajar mengajar, adanya kerjasama, diskusi, dalam permainan kartu pecahan.Dengan model kooperatif learning siswa mendapatkan keberanmian untuk melakukan komunikasi, bertanya, menjawab serta memberikan masukan terhadap persoalan yang sedang dihadapi.

Proses pembelajaran yang dirancang dengan baik lewat penyususnan RPP dan bahan ajar yang telah disiapkan, pelaksanaannya telah sesuai dengan RPP sehingga proses belajar mengajar lebih terarah dan sistematis.

\section{Daftar Pustaka}

Aqib, zainal. (2006) . Penelitian Tindakan Kelas untuk guru. Bandung : Yrama widya

Depdiknas. (2003). Kurikulum 2004 Standar Kompetensi Mata Pelajaran matematikas Sekolah dasar. Jakarta : Depdiknas .

Depdiknas. (2006). Permendiknas nomor 24 tentang pelaksanaan permendiknas no 22,23 tahun 2006. Jakarta: Depdiknas

Depdiknas. (2005). Kurikulum 2004 Pedoman Khusus Pengembangan Sistem Penilaian Berbasis Kompetensi Sekolah Menengah Pertama Mata Pelajaran Ilmu Pengetahuan Alam. jakarta: Depdiknas.

DePorter, Bobbi., Readon, Mark., dan Nourie, Sarah Singer. (2005). Quantum Teaching: Mempraktikan Quantum Learning di ruang Kelas. Bandung: Kaifa.

Ibrahim, M., Rachmadiarti, F., Nur, M., dan Ismono. (2000). Pembelajaran Kooperatif. Surabaya: University Press UNESA.

Nasution. (2000). Didaktif Asas-Asas mengajar. Jakarta : Bumi Aksara.

Nur, Hamim. (2009). Penelitian Tindakan Kelas. Surabaya: Revka Petra media.

Rachmadiarti, Fida. (2003). Pembelajaran Kooperatif. Jakarta: Proyek Peningkatan Mutu SLTP. 
Rj.Soenarjo. (2006). Matematika SD dan Mi kelas 5. Jakarta: pusat perbukuan Depdiknas

Suharsimi., Suhardjono., dan Supardi. (2006). Penelitian Tindakan Kelas. Jakarta: Bumi Aksara.

Trianto. (2009). Mendesain model pembelajaran inovatif kreatif. Jakarta: Kencana Prenada group.

Wahyu. (2005). Kooperatif learning sebagai model pembelajaran. TP’05 Community. 